\title{
RESCUING IMPOSSIBILITY DOCTRINE: A POSTMODERN FEMINIST ANALYSIS OF CONTRACT LAW*
}

\author{
MARY JOE FRUG†
}

In this Essay, I seek to enrich contract doctrine by using feminist strategies as a means of contesting and restructuring conventional and stalemated understandings. At the same time, I hope to contribute to feminist theory by exposing, on the somewhat unlikely terrain of the common law, how conventional analytical devices are deeply implicated in the construction of our current gender system. In the pursuit of these objectives, I am going to be particularly concerned with three "texts." The "texts" are law review articles written by male legal scholars for a law readership.

I originally chose the doctrinal problem I am going to discuss for a research project as a result of political happenstance. In 1988, a contracts scholar, who was then serving as chair of the Contracts Section of the Association of American Law Schools, declined a proposal for a joint Association program with feminists. In a publicly circulated letter, the chair explained his decision by elaborating his view that the topic of the relationship between feminist theory and contract law was not "developed . . . to a point where it is ready for such a sponsorship," that it does not yet have "a respectable basis." "In contrast," he wrote, the topic upon which the Contracts Section would focus its program, "excuse of

* () Copyright 1992, Gerald E. Frug.

+ Professor of Law, Villanova Law School, 1974-1981; Professor of Law, New England School of Law, 1981-1991. Mary Joe Frug was murdered on April 4, 1991; this Essay was left in draft at the time of her death. Earlier versions were presented at a program co-sponsored by the Section on Women and Legal Education and the Society of American Law Teachers at the Annual Meeting of the Association of American Law Schools in January, 1989, at the University of Toronto Legal Theory Workshop in March, 1989, and at a conference of the Critical Studies and Human Research Group on "Feminist Theory and the Question of the Subject," held at U.C.L.A. in May, 1990.

${ }^{1}$ Letter from W. David Slawson, Professor of Law, University of Southern California, to Mary Joe Frug, Professor of Law, New England School of Law 1-2 (June 24,1988 ) (circulated to the members of Professor Slawson's advisory committee) (on file with the University of Pennsylvania Law Review). 
performance, adjustment of contract and limitation of remedy on account of unexpected events," "has been thoroughly developed in the literature. $" 2$ Feminist theory, he concluded, was unlikely (ever) to contribute significantly to contract law because "the male bias of our society ... has not had important consequences for contract law. ${ }^{3}$

Since debates regarding different ways of handling doctrinal problems are a staple component of legal scholarship, I immediately decided to challenge his prediction by writing, as a feminist, about whatever doctrinal issue his group was discussing at the time. In a coincidence that may arouse your interest as it did mine, the contract doctrine I blindly assigned myself uncannily resonates with a postmodern stance toward the female subject. "It is impossible to dissociate the questions of art, style and truth from the question of the woman, ${ }^{4}$ Derrida writes in Spurs.

Nevertheless the question "what is woman?" is itself suspended by the simple formulation of their common problematic. One can no longer seek her, no more than one could search for woman's femininity or female sexuality. And she is certainly not to be found in any of the familiar modes of concept or knowledge. Yet [he concludes] it is impossible to resist looking for her. ${ }^{3}$

"[I]mpossible to dissociate ..." and "impossible to resist looking ...." The contract doctrine which is the subject of the "texts" I will discuss is the doctrine of impossibility.

\section{INTRODUCTION}

The "texts" involving impossibility doctrine that I am going to discuss are an essay by Richard Posner and Andrew Rosenfield in the 1977 Journal of Legal Studies; 6 Robert Hillman's 1983 Cornell Law Review essay; ${ }^{7}$ and a second Hillman piece which is in the 1987 Duke Law Joumal. ${ }^{8}$ These articles are important because they

2 Id. at 2.

${ }^{3}$ Id.

4 JACQUES DERRIDA, SPURS: NIETZSCHE's STYLES 71 (Barbara Harlow trans., 1978) (emphasis added).

${ }^{5} I d$. (emphasis added).

${ }^{6}$ Richard A. Posner \& Andrew M. Rosenfield, Impossibility and Related Doctrines in Contract Law: An Economic Analysis, 6 J. LeGAL STUD. 83 (1977).

${ }^{7}$ Robert A. Hillman, An Analysis of the Cessation of Contractual Relations, 68 CORNELL L. REV. 617 (1983).

${ }^{8}$ Robert A. Hillman, Court Adjustnent of Long-Term Contracts: An Analysis Under Modem Contract Law, 1987 DUKe L.J. 1. 
capture the conflict within the academic dispute about the application of impossibility doctrine. I am going to argue that the rhetoric and analytical characteristics of the Posner/Rosenfield position on impossibility doctrine are helpfully understood as stereotypically masculine, both in their strengths and in their weaknesses. In contrast, the Hillman article is helpfully understood as offering a feminine alternative version of the doctrine, with the strengths and weaknesses associated with that stereotypical position.

As Fran Olsen has written in her article, "The Sex of Law," it is often the case when opposing discourses develop, in law but also elsewhere, that the relationship between the dichotomies in the opposing discourses is likely to mirror cultural stereotypes of women and men. ${ }^{9}$ Identifying the gendered character of the discourses can therefore be a feminist strategy for challenging the extensive and complicated network of social and cultural practices which legitimate the subordination of women. The assumption underlying this strategy is that language is a mechanism of power, that there is always more at stake in the relationship of gender and language than "just" a question of literary style-indeed, that style itself can constitute a powerful socializing apparatus.

There are at least three forms which such a feminist strategy can take. One form, which I will not pursue in this Essay, focuses on the specific gender of individuals noted in a text, analyzing the ways in which male and female characters and even their pronouns are deployed. This practice is illustrated by some of my argument in reviewing Dawson, Harvey, and Henderson's fourth edition, ${ }^{10}$ such as the assertion that the disproportionate number of male parties in the cases reproduced in that text is likely to foster sexist attitudes in readers regarding the position of women or womanly persons in the law.

A second form of feminist discourse practice is to examine the relationship between the dichotomies in a particular discourse and cultural stereotypes of women and men. Such dichotomies are often unconsciously but sometimes consciously molded by their authors to resonate with stereotypical sex differences. In this Essay

${ }^{9}$ See Frances Olsen, The Sex of Law 1-2 (Dec. 14, 1988) (unpublished manuscript, on file with the University of Pennsylvania Law Review).

${ }^{10}$ See Mary Joe Frug, Re-Reading Contracts: A Feminist Analysis of a Contracts Casebook, 34 AM. U. L. REV. 1065 (1985). 
I am going to argue that the academic literature on impossibility doctrine can be arranged along such a masculine/feminine axisindeed, that it is hard to avoid the sense that this work involves unconscious self-stereotyping around gender categories.

A third form of feminist discourse analysis is to show the way meaning can acquire gendered overtones through the use of rhetoric which a reader consciously or unconsciously registers as sexual double entendre. Thus, I am going to argue that the Posner/ Rosenfield and the Hillman articles contain rhetoric which is repeatedly suggestive of stereotypical male and female "sex talk."

Before turning to a discussion of the articles themselves, let me state in a generalized way some of the reasons why I believe that analyzing the gender of legal discourse is useful. First, to the extent that there is a cultural compulsion to maintain the gendered integrity of texts, pursuing the gendered character of a particular text is likely to facilitate a reader's understanding of that text. For example, having identified the Posner/Rosenfield piece as stereotypically masculine, my appreciation of the authors' technical argument about impossibility doctrine is likely to be enhanced by using my understanding of masculinity as a stereotyped role, persona, or mask as a guide to its meaning.

Second, because of the relational character of gendered identities, a reader's understanding of opposing discourses can be furthered by using a gendered trait within one discourse to predict, to understand, or to critique the other. In addition, the hierarchical dimension of gender relations can illuminate the positioning of opposing discourses. In legal debates about doctrinal problems it is almost always the case that one line of thought is understood as the standard or dominant approach, and the second line of thought is treated as exceptional or subordinate to the first. Identifying the gender mask an author assumes not only helps predict which hierarchical position a text will occupy but may also help one understand its entrenchment in that position.

Finally, and perhaps most significantly, the gendered character of discourse can expose weaknesses in legal argument. The cultural compulsion to maintain the gendered identity of one's text involves one-inevitably, perhaps-in the vices of one's virtues. Finding ruptures in a text where its gendered character falters is likely to indicate a problem in the line of thought the text is developing.

One last point of introduction might also be useful-a brief definition of two phrases I have already used in this Essay, feminist theory and impossibility doctrine. I am usually reluctant to define 
feminist theory separately from the broader, more politically charged category of "feminism" on the grounds that this division can lead to a falsely abstracted and misleading unification of feminist projects. Nevertheless, it seems fair to acknowledge that, like other political movements, feminism has a discourse of explanation which can reasonably be called "theory." I am not sure that much feminism will be excluded by my definition of theory as work which seeks to account for the condition of women as well as to illustrate it or oppose it, but this definition has the important virtue of being supple enough to include multiple and even inconsistent categories of explanation.

Although categories within feminist theory are imprecise and overlap, the treatment of impossibility doctrine I will offer here is primarily informed by postmodern feminism, the particular blend of psychoanalysis, linguistics, and philosophy which is concerned with sexual difference and which is associated with the writing of French feminists such as Luce Irigaray and Julia Kristeva and American feminists such as Barbara Johnson and Jane Gallop. ${ }^{11}$ In acknowledging the influence of postmodern feminist scholarship, I do not mean to imply that I am conforming to an orthodox methodology or line. I doubt that I am. What does link this paper programmatically with postmodern feminism is a shared intention to disrupt cultural dichotomies-especially, and controversially, the dichotomy of male/female.

Other feminist theories, such as socialist feminism, cultural feminism, lesbian feminism, and the feminism of women of color might also inform and affect a doctrinal analysis of impossibility, although they also might not. For the purposes of this Essay I have quite deliberately overlooked the diversity of feminist theory and the conflict within feminist theories, concentrating instead on the assistance which postmodern feminism has been able to offer my undertaking.

11 See, e.g., JANE Gallop, THE DAUGHTER's SEDUCtion: FEMINISM AND PSYCHOANALYSIS (1982) [hereinafter GALLOP, SEDUCTION]; JANE GALLOP, THINKING THROUGH THE BODY (1988) [hereinafter GAILOP, THINKING]; LUCE IRIGARAY, SPECULUM OF THE OTHER WOMAN (Gillian C. Gill trans., 1985); LUCE IRIGARAY, THIS SEX WHICH Is NOT ONE (Catherine Porter trans., 1985) [hereinafter IRIGARAY, THIS SEX]; BARBARA JohnSON, THE CRITICAL DIFFERENCE (1980); BARBARA JOHNSON, A WORLD OF DIFFERENCE (1987) [hereinafter JOHNSON, A WORLD]; JULIA KRISTEVA, DESIRE IN LANGUAGE: A SEMIOTIC APPROACH TO LITERATURE AND ART (Thomas Gora et al. trans., 1980); JULIA KRISTEVA, THE KRISTEVA READER (Toril Moi ed., 1986) [hereinafter KRISTEVA, READER]. 
The term impossibility doctrine has generally been used to refer to a particular subcategory of law relating to cases in which contractual parties seek to escape their contractual responsibilities on account of "extraordinary," "unanticipated," or "disruptive" circumstances. Other subcategories are the doctrines of mistake, frustration of purpose, commercial impracticability, and failure of presupposed conditions. Like others currently writing about these subcategories, I think the commonalities among the doctrines are more usefully examined than the distinctions. ${ }^{12}$ Although elsewhere these doctrines have been referred to collectively as excuse, discharge, or cessation law, I am going to use the term impossibility as a unifying name. I have chosen this name to indicate a deliberate break with the gendered character of current scholarship. In order for feminist theory to rescue (re-skew) excuse doctrine from (within) the respectable debate in which it is currently stuck, $I$ intend to argue, descending only for the moment into postmodern jargon, that excuse doctrine is "impossible," that impossibility doctrine is the differance of contract law. ${ }^{13}$

\section{The Posner/Rosenfield and Hillman ARTicles}

\section{A. The Gendered Character of Impossibility Scholarship}

I begin with the gendered character of the position Posner and Rosenfield take on impossibility doctrine. Summarily dismissing prior attempts to predict when performance will be excused-" The foreseeability test . . . is non-operational . . ."14-the authors articulate a new standard for deciding when contract performance should be excused. "[D]ischarge should be allowed," they propose, whenever "the promisee is the superior risk bearer." 15 This standard is applied through a three step analysis, in which a

12 See, e.g., FRIEDRICH KeSSLER ET AL., CONTRAGTS: CASES \& MATERIALS 861-976 (1986) (discussing the "jurisprudential misfortune" of courts treating mistakes different from impossibilities or frustrations); Hillman, supra note 7, at 617-18 (arguing that the various doctrines for cessation are treated similarly by the courts); Hillman, supra note 8, at $\mathbf{3 1}$ (arguing that court intervention should be standardized for certain "impracticable" circumstances); Posner \& Rosenfield, supra note 6, at 8586 (asserting that the treatment of contract-discharging doctrines alike for purposes of analysis is most useful).

13 See generally JACQUes DERRIDA, Différance, in MARgnNs of PHILOSOPHY 1-27 (Alan Bass trans., 1982).

${ }^{14}$ Posner \& Rosenfield, supra note 6, at 100.

${ }^{15} \mathrm{Id}$. at 90. 
decision maker determines a) which party can estimate the probability of loss; b) which party can estimate the magnitude of the loss; and c) which party is better situated to insure against the loss. ${ }^{16}$ Posner and Rosenfield confidently claim that the "superior risk bearer" standard can explain "the typical outcomes in the major classes of cases." 17 To the extent that decided cases are inconsistent with the standard, the authors are unperturbed. "It is not our purpose to explain or even identify every inconsistent outcome." 18 To the extent that the application of the test points in opposite directions, the authors' confidence in their standard is undiminished; they assert that "empirical studies" will resolve such conflicts. ${ }^{19}$

Like a phallus, this conceptual proposal is singular, daunting, rigid, and cocksure. The purpose of the "superior risk bearer" standard, as they see it, is to permit courts to decide impossibility cases as if the singular legitimate decisional objective is to facilitate efficient contract planning. ${ }^{20}$ (In other words, the only purpose of the legal impossibility standard is to guide parties in future cases so that they can minimize drafting time and effort; the standard is unconcerned with parties already in contractual relationships who desire to know what their responsibilities might be should performance begin to seem "impossible.") In pursuit of future contract planning, Posner and Rosenfield treat all contracts as if they fit a particular, abstract model of contractual relations, in which the relationship between the parties is highly delineated and quite historically discrete. ${ }^{21}$ Finally, the authors rely on and defend a sharply and cleanly dichotomized system of contractual remedies, according to which contractual obligations must either be performed in full or discharged. ${ }^{22}$ Because the proposal is focused on a single goal, because it is confidently predicated on an abstract model of contractual relations, and because of its clearly decisive, on or off remedial implications, the characteristics of the Posner/

${ }^{16}$ See id. at $90-92$.

17 Id. at 100.

${ }^{18} \mathrm{Id}$.

19 See id. at 102, 108.

${ }^{20}$ See id. at 90.

21 See, e.g., id. at 98 (using the economically-based discharge doctrine "to supply those contract terms that the parties would have adopted if they had negotiated expressly over them").

${ }^{22}$ See, e.g., id. at 110 (comparing the breach/discharge dichotomy to the strict/no liability choice). 
Rosenfield impossibility standard correspond to stereotypical male virtues.

Hillman's article presents a sharply contrasting approach to impossibility doctrine along all the dimensions I have just mentioned. His approach actually rejects all three characteristics of the "risk bearer" standard. Thus, Hillman proposes that courts apply impossibility doctrine to serve a number of goals besides the facilitation of future contract planning. These goals, which Hillman calls "fairness norms," include favoring the party with greater equities, rewarding efforts to avoid harm to the other party, rewarding reasonable conduct, and achieving reciprocity in a deal. ${ }^{23}$ Hillman explicitly grounds his proposal, following Ian Macneil, ${ }^{24}$ in a pluralistic, context-sensitive model of contract relations, emphasizing that in the real world many contracts are based on long-term relationships in which the parties rely on good faith, forbearance, and sharing, rather than insisting on a literal interpretation of their contract texts. Finally, Hillman, like Richard Speidel, ${ }^{25}$ seeks to modify the rigid dichotomy of performance or discharge, arguing for an examination of the actual harm being caused to a party and urging that a duty of adjustment should be judicially inferred in some situations. ${ }^{26}$ Because Hillman's impossibility proposal is characterized by a concern for multiple objectives, by an appreciation of contextualized relationships, and by a desire to achieve flexibility and sharing in the administration of contract remedies, his proposal neatly fits the popular interpretation of Carol Gilligan's depiction of the virtuous feminine attitudes toward justice. ${ }^{27}$

${ }^{23}$ See Hillman, supra note 7, at 629-39.

${ }^{24}$ See IAN R. MACNEIL, THE NEW SOCLAL CONTRACT: AN INQUIRY INTO MODERN CONTRACTUAL RELATIONS 44-47 (1980).

${ }^{25}$ See, e.g., Richard E. Speidel, Court-Imposed Price Adjustments Under Long-Term Supply Contracts, 76 Nw. U. L. REv. 369, 370 (1981) (discussing the appropriateness of court-imposed adjustments of contract terms); Richard E. Speidel, Excusable Nonperformance in Sales Contexts: Some Thoughts About Risk Management, 32 S.C. L. REv. 241, 270-71 (1980) (arguing that there is a role for court adjustment in impracticable circumstances).

${ }^{26}$ See generally Hillman, supra note 8, at 19-33 (describing the circumstances under which court adjustment may be appropriate).

27 See CAROL GILLIGAN, IN A DIFFERENT VOICE: PSYCHOLOGICAL THEORY AND WOMEN'S DEVELOPMENT 18, 30, 62-63 (1982). For an analysis of Gilligan's influence in legal scholarship, see Mary Joe Frug, Progressive Feminist Legal Scholarship: Can We Claim "A Different Voice"?, 15 HARV. WOMEN's L.J. (forthcoming 1992). 
The gendered opposition between the Posner/Rosenfield article and Hillman's articles accentuates Hillman's sometimes explicit but often implicit criticism of the masculine impossibility position. Simply by concretizing and disaggregating an abstract model of contractual relations and by pointing out the merit of expanding conventional remedial options, Hillman's articles offer a critique of the male model which is both powerful and also reminiscent of typical feminine criticisms of masculinity. That is, Hillman's equitable approach suggests the element of arbitrariness in imposing the "superior risk bearer" standard in situations where it might have little to do with what the parties actually intended. The gendered opposition between the Posner/Rosenfield article and the Hillman articles also suggests the incomplete and partial character of each position.

I turn now to the sexual double entendre of the rhetoric in these articles. The tone of the Posner/Rosenfield article strikes me as markedly masculine. The article bristles with such cockiness that some of the authors' relatively commonplace law review language takes on the overtones of locker-room swagger as I read it. For example, the authors observe that conventional legal categories in this area of law are "empty," ${ }^{n 8}$ and they comment that even the most promising branch of scholastic commentary is "sterile." 29 In their promise to do something about this situation, they boast that they will "give content" to an economic analysis of the doctrine. ${ }^{30}$

These observations undoubtedly contribute to the suggestive significance I find in the authors' disregard of the phrase "impossibility doctrine" throughout the body of their article. Despite having used the phrase in their title and in subtitles, elsewhere they almost exclusively describe their subject in terms of "discharge," "discharge cases," and "discharge law." In my judgment, the depth of the authors' substantive bias in favor of contract performance and against discharge is emphasized by the contrast between the word "performance" and its association with completed, conventional heterosexual intercourse, and the association between the word "discharge" and its overtones of coitus interruptus, nocturnal emissions, and masturbation. The rhetorical impression of maleness

${ }^{28}$ See Posner \& Rosenfield, supra note 6, at 86 ("Since the typology is empty . . . [it] has led legal scholars to despair of generalizing fruitfully about the discharge problem.").

${ }^{29}$ See id. at $87-88$ ("[T]

${ }^{30}$ See id. at 88. 
this article conveys is partly derived from the sense that these two contrasting categories of sexual activities define the authors' limited, stereotypically masculine erotic universe.

In contrast to the Posner/Rosenfield article, the structure, tone, and language of the Hillman articles have feminine overtones. Hillman's tone is unintimidating, accommodating, and unassuming, not cocksure. His position on impossibility is set forth in two articles and developed through four fairness norms; it has multiple parts. In contrast to the daunting Posnerian tone, Hillman modestly describes his impossibility standard as "supplement[al]" to the principle of "freedom of contract"; ${ }^{31}$ he deferentially places his standard regarding excuse of performance after a discussion of the express and implied desires of contract parties. ${ }^{32}$ Read in comparison with the Posnerian rhetoric, Hillman's tropes, the figurative language he uses, evoke a stereotypically female description of sexual relations. 'Hillman's unifying name for impossibility doctrine is "cessation" rather than "discharge," and rather than promising to "give content" to an analysis or erect a "framework" he uses the language of display: he promises to "present," to "demonstrate" his thesis. ${ }^{33}$ His frequently stated and principal concern is the application of impossibility law where parties have left "gaps" in their contracts. ${ }^{34}$

\section{B. Dismupting the Gendered Opposition of Impossibility Scholarship}

Like other postmodern theorists, postmodern feminists use deconstructive analytical strategies to expose contradictory and repressed elements embedded within and supporting the deceptively coherent message on the surface of a text. The strategy I will use here-a strategy inspired by Jane Gallop's most recent book, Thinking Through the Body ${ }^{35}$-consists of identifying what I call a critical rupture in a passage; a rupture which, in Barbara Johnson's words, "encounters and propagates the surprise of otherness" or

${ }^{31}$ See Hillman, supra note 7, at 620 .

32 See id. at 620-29 (discussing express and implied desires of contracting parties); id. at 629-42 (describing a model of "fairness in contract cessation").

${ }^{33}$ See id. at 620 ("In the conclusion, I present some brief observations based on the survey in Part II."); id. at 617 ("My first goal is to demonstrate that the courts generally have taken a common approach to the issue of cessation.").

${ }^{34}$ See id. at 627 (discussing, under the subheading "Gaps," failures of certain contracts to "consider and plan for contingencies that will arise").

${ }^{35}$ See Gallop, THINKING, supra note 11 . 
difference. ${ }^{36}$ In each of the texts I examine, the critical rupture is a point where analytical cogency is sacrificed to the gendered integrity of the authors' positions.

A critical rupture in the Posner/Rosenfield article occurs at the moment two-thirds of the way into the article when the authors briefly discuss "doubtful cases." ${ }^{37}$ "Doubtful cases" are defined as those in which the "superior risk bearer" test "will fail to yield a definite answer." ${ }^{38}$ In singling out "doubtful cases" for separate treatment Posner and Rosenfield seem about to face a critique of their own proposal. They seem about to stray from the firm and confident masculinity that has characterized their argument. Doctrinally the authors could have chosen one of at least three solutions for cases which the risk bearer standard does not explain. They could have recommended discharge; they could have recommended, as they did, that parties be required to perform; or they could have recommended that "doubtful cases" be subject to an equitable approach, such as the one Hillman proposed. That is, they could have chosen a solution that would have broken the absolutism of the "superior risk bearer" standard by taking into account the situation of the parties after the contract had been formed.

The authors reject a Hillman-like solution. Their solution is decisive but largely unexplained. "Pending definitive empirical study," they say that the appropriate resolution of doubtful cases is to reject the application of impossibility doctrine and reaffirm the principle of strict liability in contract. ${ }^{39}$

By rejecting an equitable approach, with its attendant uncertainty, Posner and Rosenfield refuse an open solution that would have been inconsistent with the closure they seek. An equitable approach, as Hillman himself points out, is subject to criticism because it pursues fairness at the cost of certainty. ${ }^{40}$ By rejecting discharge and requiring parties to perform, Posner and Rosenfield choose an authoritarian rather than a permissive solution for "doubtful cases." Confronting a threat to the logic of their argument (confronting, one might also say, difference, or woman), their response exhibits the weaknesses stereotypically associated with masculinity: they are

\footnotetext{
36 JOInsON, A WORID, supra note 11 , at 15.

${ }^{37}$ See Posner \& Rosenfield, supra note 6, at 110-11.

${ }^{38} \mathrm{Id}$. at 110.

${ }^{39}$ See id.

${ }^{40}$ See Hillman, supra note 7, at 659.
} 
arbitrary, rigid, and authoritarian. They are unable to claim what Keats called "Negative Capability"-the capacity "of being in uncertainties, Mysteries, doubts, without any irritable reaching after fact \& reason. ${ }^{n 1}$

Although there is much to admire in Hillman's impossibility proposal, analyzing the feminization of his work similarly helps reveal the problems that adhere in his approach. A critical rupture in Hillman's proposal occurs in a short section where he concludes his presentation of the "fairness norms." Although he has earlier claimed that the "fairness norms" can "explain" impossibility decisions ${ }^{42}$ and has minimized the Posnerian standard as "only of limited help, "43 here he aclnnowledges the significance of the Posnerian proposal, admitting that "[c]ourts sometimes justify cessation decisions .... on the economic and social policies of avoiding economic waste and promoting the economy through contract formation." ${ }^{\text {44 }}$ Hillman seems about to analyze the relationship between his standard and the "superior risk bearer" principle; he seems about to confront a masculine challenge to the feminine virtues of his proposal.

This moment in Hillman's piece, the point when a tough question is raised in the text, parallels the Posner/Rosenfield examination of "doubtful cases." But unlike their decisive, if arbitrary, resolution, Hillman is contradictory and conciliatory. Stating at first that he must avoid the question, because the relationship between the two standards is "complex" and "beyond the scope of this paper, ${ }^{45}$ he immediately reverses this decision, allowing himself "some brief observations." A6 Among these observations is the disingenuous claim that the two standards "generally dictate the same result" since the two standards "correspond." Hillman introduces this latter claim with a conventional feminine disclaimer. "Intuitively," he begins. "Intuitively, waste-avoidance and preserving the benefits of contract-

41 Letter from John Keats to George and Tom Keats (Dec. 22, 1818), in 1 THE LETTERS OF JOHN KEATS: 1814-1821, at 193 (Hyder Edward Rollins ed., 1958).

${ }^{42}$ See Hillman, supra note 7, at 618-19 ("My second goal is to explain the common approach to cessation. ... Four interrelated fairness norms figure prominently in such analysis.").

${ }^{43} \mathrm{Id}$. at 626.

$44 \mathrm{Id}$. at 640 .

${ }^{45} \mathrm{Id}$. at $640-41$.

${ }^{46} I d$. at 641 .

${ }^{47} \mathrm{Id}$. 
ing through 'keeping the deal together' correspond with protecting the substantial reliance interest of a party on harm-avoidance grounds. $" 48$

The Posnerian and Hillman standards are concerned with different kinds of unexpected losses. The Posnerian standard implements the allocation of estimated losses behind the veil of history. It seeks to determine what the parties should have decided about allocation before the unexpected event occurred. In contrast, Hillman's standard is concerned with the distribution of actual losses. There is no reason to believe the standards would yield the same outcomes. To reconcile his standard with the Posnerian version Hillman misstates the efficiency standard by linking it with his goal of "keeping the deal together." The feminine virtue of Hillman's article thereby ruptures in this passage: confronting the threat of difference between his argument and another's, Hillman's response exhibits the stereotypical weaknesses associated with femininity: he appeals to intuition to cover a slight misrepresentation, using misrepresentation as it is commonly deployed to mitigate the feminine terror of confrontation, argument, and autonomy.

Although the texts I have been discussing seek to provide a useful legal standard by which to determine how impossibility doctrine is applied, they therefore fail in their objectives. Just as Hillman's legal argument fails when the gendered persona of his text falters and is reasserted, so Posner and Rosenfield's attempt to develop a legal standard for impossibility fails at a point of crisis in the gender role of their text. By asserting that "doubtful cases" should not be excused, they avoid discharge and call on the parties for performance. Masculine cockiness thus identifies the point at which Posner and Rosenfield abruptly abandon the project of delineating a legal standard for impossibility doctrine and arbitrarily reinstate the principle of strict liability in its place.

\section{The Gendered Context of Impossibility Doctrine}

Thus far my analysis of current impossibility literature has used reading strategies inspired by postmodern feminism in order to expose shortcomings in current approaches to the problem of impossibility. Let me now indicate briefly how feminist theory might yield constructive insights regarding the generation of persuasive doctrinal argument in impossibility cases.

${ }^{48} I d$. (emphasis added) (citation omitted). 
One idea is to explore the striking parallels between impossibility doctrine and the character and development of divorce and annulment law. Like impossibility doctrine, the function of annulment and divorce is specifically to excuse performance of obligations imposed by the contractual relations of the parties. ${ }^{49}$ But the analogies between these fields have historically been foreclosed to contract disputes because of the segregation of the legal subject areas. Because of women's historical links to and dependence on the domestic sphere, the segregation of these areas has a decidedly sex-based character. This sex-segregated character seems particularly pronounced in the context of the nineteenth century, when impossibility doctrine was purportedly "formed." At that time the contracting activity of married women was largely confined to their marriage contracts. Until the reforms begun in the mid-nineteenth century by the Married Women's Property Acts, the law relating to the contracts most women entered was separated from the law of other contracts. ${ }^{51}$

I think it would be useful for feminists to elaborate the historically gendered roots of current impossibility doctrine, seeking to determine the effect on impossibility doctrine of placing it in a broader context. ${ }^{52}$ One could, for example, track the parallels of the changing remedial consequences of divorce and impossibility over time, seeking-with some caution-to determine the significance of the historical separation between these two similar doctrinal areas. Like impossibility doctrine of the same period, the law of

${ }^{49}$ See 1 Theophilus Parsons, The LAW OF Contracts 384 (1980) (impossibility defense); 11 id. at 556 (marriage contracts).

${ }^{50}$ Impossibility doctrine was purportedly "formed" in the early or mid-nineteenth century. See GRANT GILMORE, THE DEATH OF CONTRACT 138 n.206 (1974) (crediting Tarling v. Baxter, 108 Eng. Rep. 434 (1827), as the early leading case); Leon E. Trakman, Winner Take Some: Loss Sharing and Commercial Impracticability, 69 MINN. L. REv. 471, 475 (1985) (crediting Taylor v. Caldwell, 122 Eng. Rep. 309 (1863)). Paradine v. Jane, 82 Eng. Rep. 897 (1647), is conventionally cited as evidence that impossibility doctrine did not exist earlier. See, e.g., KESSLER ET AL., supra note 12, at 913. This case raises for me, however, the possibility that the doctrine in fact predates the nineteenth century, since such a "rejection" could be understood as a recognition of the doctrine coupled with a refusal to utilize it.

${ }^{51}$ See Frances Olsen, Statutory Rape: A Feminist Critique of Rights Analysis, 63 TEX. L. REv. 387, 399 n.56 (1984) ("Until the passage of the married women's property acts in the late 19th century, married women were legally incompetent to bind themselves by contract.").

52 The methodology of this section is consistent with the long-standing feminist practice of analyzing the consequences for a particular discourse of omitting women or topics which particularly interest or involve women. 
divorce in mid-nineteenth century American legal history offered parties narrower opportunities for excuse of contract performance than is true today. Unlike the consequences of impossibility doctrine, however, the use of divorce did not always fully discharge marital contracts, in that alimony awards functioned in many cases to extend a husband's duties of marital support after divorce had terminated his marital status. ${ }^{53}$

In this century Ian Macneil and others have argued that contract doctrine ought to take into account, rather than suppress, the interest which contract parties may have in preserving their relationship beyond the event giving rise to an impossibility dispute. ${ }^{54}$ Indeed, Macneil is often cited by those, like Hillman and Speidel, who seek to encourage a duty of adjustment in certain impossibility situations. There is a remarkable similarity between Macneil's description of "relational" contract law and its remedial consequences and the typical descriptions of marriage and divorce law which preceded the divorce reforms of the early 1970s. Despite the warm reception that Macneil's proposals have received among some contract scholars, there is a remarkable silence regarding his work among others, including, not surprisingly, Posner and Rosenfield.

Another potentially fruitful comparison between the law of divorce and impossibility doctrine in the mid-nineteenth century is likely to be the acknowledged interest of the state in divorce suits. In the classical treatment of impossibility issues, the public interest was so decisively banished from explicit consideration that courts often heavily and unsubtly deployed the device of an invented "implied condition" to determine whether excuse was warranted, a device subjected to increasing criticism after the turn of the century. ${ }^{55}$ In contrast, a marriage and divorce treatise writer of the mid-nineteenth century describes the public interest in divorce litigation as the "one great controlling principle running through all matrimonial suits, and bringing into subserviency all other law on the subject. ${ }^{56}$ Indeed, in at least two states a public prosecuting

${ }^{53}$ See JOEL P. BISHOP, COMMENTARIES ON THE LAW OF MARRIAGE AND DIVORCE, AND EVIDENCE IN MATRIMONLAL SUITS $\$ \S 548-590$ (Boston, Little, Brown 1852).

${ }^{54}$ See supra note 24 and accompanying text.

55 See 5 SAMUEL WiLliston, A TREATISE ON THE LAW OF CONTRACTS \$\$ 668-669 (Walter Jaeger ed., 3d ed. 1961) ("Where ... the law itself has imposed the condition ... it can ... shap [e] the boundaries of the constructive condition in such a way as to do justice and avoid hardship.").

56 BISHOP, supra note 53, § 297. 
officer was required to participate in divorce proceedings along with the parties. ${ }^{57}$

Although the public interest in divorce continues to hover over even the most liberal no-fault divorce jurisdictions, ${ }^{58}$ the public interest in such proceedings is considerably more subtly manifested than it was in the last century; parties enjoy the appearance of more individualized control over divorce. In contrast, the public interest in impossibility disputes is more overt than it was in the last century, in part because impossibility disputes seem to arise more frequently today as a result of governmental regulatory changes than seems to have been the case in the past. The task here will be to analyze, again exercising caution, the significance of the changing roles of public interest in the separated yet analogous areas involving claims to excuse contract performance.

\section{RESCUING (RE-SKEWING) IMPOSSIBILITY DOCTRINE}

The gendered integrity that I have argued Posner/Rosenfield and Hillman tenaciously preserve in their essays is incompatible with the approach $\mathrm{I}$ attribute to postmodern feminists regarding sexual difference. There is, in fact, an illuminating parallel between the postmodern feminist desire to challenge the borders that define us as men and women and a re-skewed, cogent impossibility doctrine which is neither masculine, nor feminine, nor some confused, androgynous mixture.

Although lesbian feminists and women of color have begun to unravel the imperialistic claims many feminists make regarding women, ${ }^{59}$ postmodern feminists have theorized these challenges. They maintain that replacing male values with female values simply reallocates power between the poles of an axis; it does not challenge the confining structure of the (gendered) axis. ${ }^{60}$ Male-

\section{${ }^{57}$ See id.}

${ }^{58}$ See, e.g., CAL. Crv. Proc. CoDE $\$ 1760$ (West 1982) (providing that the family conciliation court shall have jurisdiction over "any controversy . . . between spouses [who have a minor child in their household whose welfare might be affected by the controversy] ... which may ... result in the dissolution or annulment of the marriage"); MASS. ANN. LAwS ch. 208, § IA (Law. Co-op. 1981 \& Supp. 1991) (providing that in deciding on a couple's efforts to obtain divorce on the ground of irretrievable breakdown of their marriage, "the court shall ... make a finding as to whether or not an irretrievable breakdown of the marriage exists").

${ }^{59}$ See, e.g., THIS BRIDGE CALIED MY BACK: WRITINGS BY RADICAL WOMEN OF COLOR (Cherríe Moragan \& Gloria Anzaldũa eds., 1983) (challenging feminist claims from the perspective of both lesbian feminists and women of color).

${ }^{60}$ See generally GALLOP, SEDUCTION, supra note 11, at 124 (noting that female 
ness and femaleness therefore persevere as confining and restraining consequences of biological data because of the oppositional framework in which we locate them.

Postmodern feminists seek to alter this oppositional structure by grounding their analyses of sexual difference on the structuralist insight that meaning depends on non-meaning. Maleness is not just the opposite of femaleness. Instead, maleness depends on femaleness. Unlike Posner, Rosenfield, and Hillman, postmodern feminists are willing to confront the differences within maleness or femaleness. ${ }^{61}$ At the same time, despite current claims to the contrary, ${ }^{62}$ postmodern feminists also accept sexual difference. ${ }^{63}$ Postmodern feminists are thus able to treat women as historically situated individuals with commonalities at the same time that they are challenging the link between femininity and biological femaleness.

Transposing their paradoxical approach toward sexual difference to impossibility doctrine, a postmodern feminists' observation would be that the meaning of strict liability or performance depends on the concept of what non-performance or excuse of performance would mean. Contract law is constituted by the idea that parties can count on allocating today the risks of tomorrow. By claiming that some unexpected circumstances are not allocated by contract, the doctrine of impossibility affirms the ability of contract to protect against those risks that are allocated. Impossibility doctrine is thus located at the margins of strict liability, where it constantly threatens to disrupt expectations of performance-just as postmodern feminists both acknowledge and challenge the borders that define us as men and women. Indeed it is because of this location at the margins that impossibility doctrine can perform its constituting and liberating function within contract doctrine.

theorists merely reverse the bipolar gender characterization of male theorists); KRISTEVA, READER, supra note 11, at 81-82 (discussing the Marxist view of wealth as resulting from the bipolar elements of work, which is male, and matter, which is female).

61 See, e.g., IRIGARAY, ThIS SEX, supra note 11, at 81-85 (discussing how "the double demand-for both equality and difference-[can] be articulated").

62 Postmodern feminists are increasingly charged with claims that their work is depolitical, or anti-political, or post-feminist. See, e.g., Karen Offen, The Use and Abuse of History, WOMEN'S REVIEW OF BOOKS, April 1989, at 15-16 (asking "Must the postmodernist be necessarily post-feminist?"). But see JOHNSON, A WORLD, supra note 11, at 25-31 (discussing whether "writerliness" is "conservative").

63 Jane Gallop is particularly adept at challenging the male/female opposition at the same time she disrupts it. See generally GALLOP, SEDUCTION, supra note 11. 
In their efforts to subject the problem of unexpected contract conditions to predictable standards, Posner, Rosenfield, and Hillman segregate impossibility from strict liability. This instinct toward segregation is understandable, in that oppositional relationships tend to produce hierarchies. And the value of impossibility doctrine to contracting parties would be jeopardized if the doctrine were subordinated to strict liability, just as the value of contracting would be drastically undermined if the principle of strict liability were subordinated to the doctrine of impossibility. As we have seen, however, these authors' segregating efforts devolve into yet another oppositional structure, the genderization of impossibility, and this genderization defeats the project of articulating a predictable standard of impossibility doctrine application.

I think that the quest for a predictable standard is misguidedthat impossibility doctrine must be articulated in relationship to but not in opposition to the principle of strict liability. This obligation makes the doctrine of impossibility doctrine "impossible." But I do not believe that claiming the impossibility of impossibility doctrine requires the doctrine to be consigned to the realm of the subjective, the irrational, the nihilistic, or the non-legal. My suggested feminist approach to impossibility adopts the approach postmodern feminists have used in confronting the problem of sexual difference. Postmodern feminists do not seek to help women be more like men or to replace male values with female values, or to achieve an androgynous reconstruction and unification of male and female. Postmodern feminists attempt to overcome the male/female opposition by accepting it and at the same time disrupting it.

Can feminist critical scholars claim a different voice in analyzing contract law doctrine? I hope I have conveyed that we can, in so far as the use of gender stereotypes is useful in legal analysis. I also hope I have indicated that we cannot.

"Who are we" is a penetrating question to turn on my discussion here. The feminine text I analyzed was written by a man. The stereotypes I associated with gender may not be every woman's or every feminist's. The negative stereotypes associated with Hillman's text distinguish his "voice" and mine from the upbeat version of femininity popularly attributed to Gilligan's book. ${ }^{64}$ Indeed, I am willing to admit that the particular traits I associate with masculine and feminine stereotypes are undoubtedly a product of my cultural

64 See GilligaN, supra note 27. 
INTENTIONAL BLANK 
